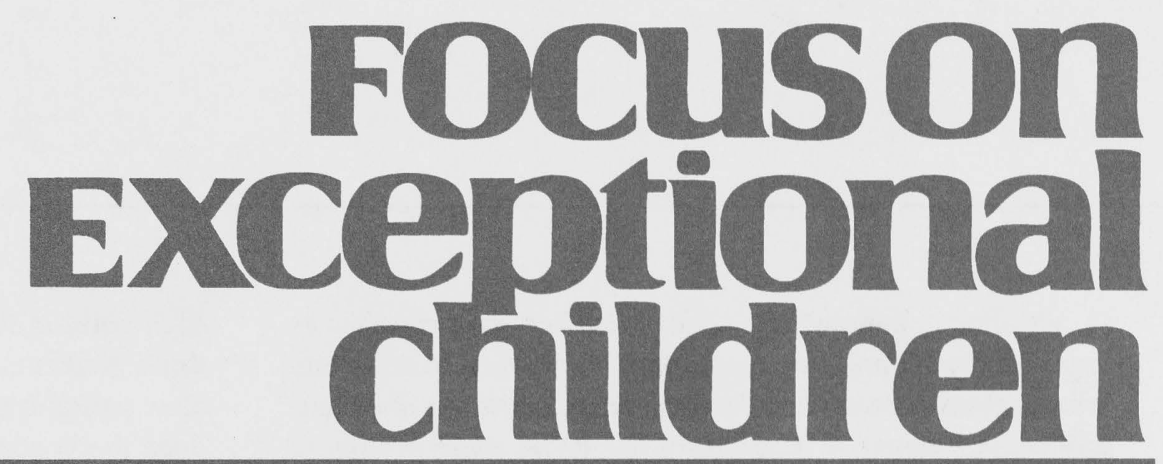

\title{
New Ways of Thinking About Assessment and Curriculum
}

\author{
Beth Berghoff
}

Almost every first grade has at least one Peter, one youngster with thick glasses halfway down his nose who comes to school wearing shoes without socks. He is a likeable guy, but he's always a little lost. His pencil is broken and chewed so that it barely writes, and he can't find his book even though it is in the pile of papers and books he is rummaging through. Peter is the child who delivers the important note from his mother at the end of the day instead of in the morning and who misses his bus because he detoured through the gym. The most troubling thing about Peter is that he is not making much progress toward learning to read and write. He has all the characteristics that mark him as being one of those children who will struggle throughout his school career.

The story that follows is Peter's story, but it is also a story about new visions of assessment embedded in collaborative teaching and multiple ways of knowing curriculum. This new view of assessment is predicated on an aesthetic view of literacy, a view that embraces the notion that literacy develops as individuals make sense of their lived experience using the full range of human meaning-making systems. From this perspective, print literacy is not a separate strand of knowing but rather a communicative skill that develops simultaneously with other knowledge and skills. Reading is thought of as a larger process than just making meaning of print. It is a process that also goes on when an individual interprets a piece of art, watches a drama, or views a film (Berghoff, 1998).

But I am getting ahead of the story. Let me back up and start again by saying that Peter's story comes from the most powerful experience I have had as an elementary teacher. Like many special educators, I was invited to collaborate with a general education classroom teacher, Susan Hamilton. Susan and I had met in a college class that challenged us to read and synthesize current research and to rethink some of our basic assumptions about literacy and curriculum. A few months after that experience, we decided to spend a year working together in Susan's urban first-grade classroom to develop curriculum that reflected the new ideas developing in the language education field and to experiment with new ways of thinking about assessment. It is that year that I am writing about.

Beth Berghoff is with the School of Education, Indiana University-Purdue University at Indianapolis, IN. This article will appear in a new book, Looking At Learning Disabilities in New Ways to be published by Love Publishing in August, 2000. 
Working collaboratively really stretched Susan and me as teachers. Being half of a team forced both of us to articulate what was on our minds and to be open to questions that challenged our tentative notions of what we were trying to accomplish. We learned to talk about our personal theories and to explain the assumptions underlying our actions. We learned that we did not always see the same things happening, that we sometimes had different lenses for viewing classroom life. We found that we could learn more about what was happening with the children if we assumed responsibility for different roles. When one of us focused on teaching small groups, the other floated around the classroom and conversed with children at work, gathering information about what they could do in a group with peers, what they chose to do on their own, and how they used literacy to interact with their peers and to learn. We benefited from having the input of our two unique perspectives when we sat down to plan curriculum or assess how the learners were doing. As with other learning processes, creating curriculum and conducting assessment became experiences with more depth and dimension when they were done collaboratively.

Susan and I agreed that the basic goals of the school curriculum should remain intact in our classroom. We wanted

\section{FOcuson
Exceptional
children}

ISSN 0015-511X

FOCUS ON EXCEPTIONAL CHILDREN (USPS 203-360) is published monthly except June, July, and August as a service to teachers, special educators, curriculum specialists, administrators, and those concerned with the special education of exceptional children. This publication is annotated and indexed by the ERIC Clearinghouse on Handicapped and Gifted children for publication in the monthly Current Index to Journals in Education (CIJE) and the quarterly index, Exceptional Children Education Resources (ECER). The full text of Focus on Exceptional Children is also available in the electronic versions of the Education Index. It is also available in microfilm from Xerox University Microfilms, Ann Arbor, MI. Subscription rates: Individual, $\$ 30$ per year; institutions, $\$ 40$ per year. Copyright (C) 2000, Love Publishing Company. All rights reserved. Reproduction in whole or part without written permission is prohibited. Printed in the United States of America. Periodicals postage is paid at Denver, Colorado. POSTMASTER: Send address changes to:

$$
\begin{gathered}
\text { Love Publishing Company } \\
\text { Executive and Editorial Office } \\
\text { P.O. Box } 22353 \\
\text { Denver, Colorado } 80222 \\
\text { Telephone (303) } 221-7333
\end{gathered}
$$

\begin{abstract}
Karen Harris
University of Maryland
\end{abstract}

James Shriner

University of Illinois
Thomas Skrtic

University of Kansas
Stanley F. Love

Publisher each child in this urban class to learn to read and write, to think mathematically, and to be successful on the measures of learning used by the school district. We wanted to introduce the concepts and knowledge identified in the science and social studies guides for first grade. In addition, however, we wanted the learners to be able to use a wide variety of sign systems to learn from experiences that evolved from their questions and interests. For this to happen, we had to significantly change the ways we set out to accomplish our goals, the "how" of the curriculum, as well as the ways we assessed the children's learning and development of literacy. We decided to build our curriculum around the following three assumptions:

- Literacy develops via multiple sign systems.

- Literacy supports the process of inquiry.

- Literacy is shaped by the learner's theories about learning and literacy.

We also decided to attempt to conduct assessment from an "aesthetic" stance.

"Aesthetic," as we were using the term, represents a concept borrowed from reading theorist Louise Rosenblatt (1978), who described reading as a continuum of possibilities that depends on one's purpose and stance toward reading. She described an aesthetic stance as one in which the reader transacts with a text to have a "lived-through" experience. The reader expects to create an imaginary world where he or she can anticipate and vicariously experience sensual pleasures or the tragedies of life. A reader taking an aesthetic stance reads a text to gather information that adds to the richness of the experience and yields more complexity to his or her understanding of events and characters. In contrast, Rosenblatt described an efferent reading stance. An efferent reader reads for the information needed to accomplish a task. The efferent reader is more interested in the efficient retrieval of information than in having a human experience.

Similarly, when we, as educators, conduct assessment in schools, we also have a range of purposes. Some assessment is meant to provide efficient accountability information. For example, a benchmark assessment may provide information about what a child can or cannot do. Another type of assessment requires that we enter the world of the child and imagine what it is like to be the child. When this kind of assessment is done, the evaluator is taking an aesthetic stance toward assessment. The purpose is to understand how the students lives and thinks; how the student likes to spend his or her time; how experiences contribute to his or her development and understanding; and what the child is likely to learn next. When an aesthetic stance is taken, the purpose is to know the lived experience of the 
child, not to check skills off a list as they are mastered. The evaluator creates his or her own story of the child and continually gathers more information to check predictions and deepen understanding.

Susan and I were beginners in this regard. We laid the path as we walked down it together. This worked well for us because we had each other and because we were clear about the assumptions we wanted to serve as the framework for our curriculum and assessment. These assumptions are explained in greater detail in the next section of this article, and examples are provided to show how we translated these assumptions into classroom practice in our first grade.

Our class was made up of a diverse group of children. Some came from the low-income neighborhood around the school; others rode the bus from an outlying working-class neighborhood. There were 10 girls and 8 boys-6 AfricanAmerican, 1 Asian, and 11 Caucasian. All of these children made good progress toward the goals of the curriculum except Peter. He struggled with print literacy. Unlike the other children who were eager to unravel the complexities of written language, Peter was reluctant to read and write. His development was painfully slow and confusing. Fortunately, we had new kinds of learning experiences happening in the classroom, and these changed what we were able to see. We were able to step back and observe Peter in an aesthetic way, seeing how he used systems other than language, and we were able to piece together his lived experience in the classroom. The second half of this article tells Peter's story and shows what we learned about Peter in our first attempts to take an aesthetic stance toward assessment.

\section{ASSUMPTIONS BEHIND AN AESTHETIC STANCE TOWARD LITERACY}

\section{Literacy Develops Via Multiple Sign Systems}

Many educators are not familiar with the term sign system because education has been almost solely focused on the single sign system of language. In part, the focus on a single sign system is historical. When the Committee of Fifteen designed elementary curriculum for public schools in 1895 (Shannon, 1990), written language was the major form of mass communication. Much has changed in the past 100 years. Today, our information comes in a rich variety of signs - think of the visual images on the Internet, the musical scores of films, the hip-hop dance of rappers on MTV, the rich variety of clothing at the shopping mall. We are no longer limited to paper and ink, yet our schools are slow to acknowledge that literacy involves more than language. We include art, music, and physical education in the curriculum, but they are often not equal partners to language and math.
The term sign system originates from the discipline of semiotics, the science of human meaning making. Sign systems like art, music, drama, mathematics, and language are communication systems. We use them to construct and express meaning. They comprise different elements and rules for combining these elements to make meaning. For example, painting uses the elements of color, line, and shape presented simultaneously to the viewer, and songs use tempo, pitch, and rhythms unfolding across time. We have multiple sign systems in our cultures because each sign system is effective in communicating certain kinds of messages. Music can express feelings that are not easily put into words; language is a better medium for humor than math; yet math can represent concepts that are not easily represented in art.

A growing body of research supports the inclusion of multiple sign systems in school curriculum. Harvard's Project Zero (Csikszentmihalyi, 1996) has demonstrated that students learn at higher cognitive levels when art and music are incorporated into learning experiences than when they are not. John-Steiner (1985) also asserted that intellectual work is richer when an individual can work with a combination of "languages of the mind." When she interviewed or corresponded with more than 100 highly creative and successful adults in such fields as mathematics, science, music, choreography, writing, and art, she discovered that these individuals do not rely solely on language to do their thinking. Rather, they work in multiple sign systems simultaneously, like British writer Margaret Drabble, who explained that, for her, writing a novel was not a matter of putting words on paper but was rather a process of listening to her dramatic inner voice and capturing the visual images of her imagination.

In the language education field, the realization that children use sign systems in flexible ways was first documented by Harste, Woodward, and Burke's study summarized in Language Stories and Literacy Lessons (1984). These researchers studied preschoolers' literacy development by asking them to write for different purposes. They observed that the children moved freely between art and writing, seeing both as valid ways of communicating their meaning. Later, Hubbard (1989) analyzed the ways in which first graders combined the use of art and writing in their work. She pointed out how thoughtfully the children allocated information between the two systems. For example, a child writing a story about a bird might provide the problem and solution in writing but then describe the features of the bird and the bird's motion in drawing.

Anyone who teaches in an early childhood setting knows that children are happiest when they can use a full repertoire of communicative systems, including dramatic play, drawing, dancing, singing, and writing. Children do what Newkirk 
(1989) described as "symbol weaving"; they sing while they paint and dance as they reenact a story. They use sign systems in flexible and intertwining ways to explore the world and make meaning.

In the school where Susan and I worked, first grade was the place where symbol weaving stopped being appropriate. In the first-grade classrooms, children were trained to work quietly on paper and pencil activities. The classroom lessons focused largely on language and numeracy, while art, music, and movement were studied in special classes for $30 \mathrm{~min}-$ utes once or twice a week. As in school systems all over the country, this school system put a premium on language arts and mathematics test scores, and the teachers believed this narrowing of the curriculum was necessary if the children were going to become proficient users of language and numbers.

While we knew it was somewhat counterintuitive, Susan and I had been convinced by our reading and discussions that it would actually be better for first graders to be immersed in multiple sign systems than to be limited to language and math. We wanted to foster children's use of a rich blend of sign systems to learn. To do that, we believed we had to support the children in becoming more sophisticated users of multiple sign systems and make multiple sign systems available as tools for learning. So we demonstrated how sign systems were used in the culture to communicate particular kinds of meanings, and we provided engagements that invited the children to explore their own questions and interests using a variety of sign systems.

For example, when we were studying Colonial America, an art teacher suggested that we introduce the children to the portrait painting typical of the era. She helped us find a packet of art print portraits that the children could examine and showed us how she often taught children to sketch faces. To give the kids a sense of the historical setting that made portrait painting an important art form, I dressed up like an itinerant painter of the mid-1700s and stopped in to see if the class would be interested in having any portraits drawn. Susan reminded the class that I was coming from a time before cameras had been invented for taking family pictures. I showed the children my portfolio of portraits from the era, and their observations about the portraits led to a discussion about the lives of children in colonial times. Once their questions had been answered, I asked for a volunteer to sit for a portrait. I set up my easel, and as I drew and colored the portrait of the child I taught the art lesson (shared by the art teacher) about sketching faces.

Demonstrations like this provided the students with information about different sign systems by providing examples of past or present use of the sign systems and information about the elements used to create meaning by each sign system. We reasoned that these demonstrations were important because they broadened the students' sense of what different sign systems did most effectively and what elements were essential to communication.

As noted earlier, we also provided engagements that invited the children to explore sign systems as a means for communicating and expressing themselves. We provided the time and materials for students to think via multiple sign systems by setting up a number of activity centers with various media and artifacts-or "invitations," as we called them-from which the children could choose each day. One invitation was called the Portrait Center. After introducing the art prints and portrait drawing to the students, for example, we set up a gallery where students could study the portraits, and we set up an easel with pastel crayons so they could draw one another. In addition to this drawing invitation, we also extended invitations on a daily basis for the students to use drama, writing, math, music, science, movement, and art to reflect on and express ideas. During their 40 to 60 minutes of daily "invitation time," the children were free to choose "invitations," or activity centers, where they wanted to work. The demonstrations we conducted in class gave them ideas about what was possible at each invitation, but they were free to go where the media and materials led them as well. The invitations were kept intact as long as students were actively using them. When the interest in an invitation diminished, we invented a new demonstration and invitation to take its place.

\section{Literacy Supports the Process of Inquiry}

Inquiry isn't just asking and answering a question. It involves searching for significant questions and figuring out how to explore those questions from many perspectives. -Short, Schroeder, Laird, Ferguson,
\& Crawford, 1996, p. 9

The whole language movement has taught educators that children do much more than just learn to use language. They learn to use language to accomplish their own purposes as learners and to participate in the social life that surrounds them. As teachers, we have a choice. We can support and guide the children's personal use of language for inquiry and social participation or we can teach some systematic language program that disconnects language learning from the children's personal questions and purposes.

Many teachers now teach in "inquiry-based" ways (Mills \& Clyde, 1990; Short et al., 1996). They appreciate that inquiry is a process of coming to know rather than a skill or step-by-step procedure. They understand that inquiry involves interests, active explorations, tensions, posing questions, hypothesizing, investigating, and constructing new understandings and new questions. They realize that the 
inquiry process is dependent on many smaller processes, such as reading, authoring, transmediating (taking meaning from one sign system to another), conversation, and reflection. They know that children's literacy develops as children engage in these communicative processes for the purposes of answering their own questions and those of their peers (Berghoff, 1994).

In the view of many educators today, inquiry is a better vehicle for organizing curriculum than the discipline blocks of language arts, mathematics, science, and social studies, because it encourages the kind of symbol weaving that happens when children are using a full range of sign systems. Good questions cut across disciplinary boundaries and encourage students to construct knowledge that incorporates multiple perspectives.

To set up a classroom where literacy supported inquiry, Susan and I planned units around big conceptual questions that we knew were puzzling to the children, such as: What are predictable books? What was it like to live in Colonial America? What is winter? What is Africa? What is real?/What is make-believe? Each of these units lasted several weeks and involved the children in shared experiences and invitations that provided them with a great deal of information to explore and synthesize. They read, wrote, made artifacts, conversed, and reflected using all of the sign systems, not just language. Then we encouraged the children to formulate personal inquiry questions, to conduct personal explorations, and to share their new understandings with the class.

Across the span of the year, we saw the students internalize the inquiry process and make it their own. They began to identify books and engagements that would add to their knowledge. They watched one another and borrowed ways of organizing and representing their knowledge. They eagerly discussed their ideas and asked new questions. They grew very patient with one another, really listening to others and asking good questions.

\section{Literacy Is Shaped by the Learner's Theories}

One difficulty we faced as we changed our teaching to demonstrate our new beliefs about learning and literacy was that the children did not automatically share our assumptions. They came to the curriculum with assumptions of their own about how school and literacy learning were supposed to happen. Their theories were often not easy to discern because the children were not very articulate about their theories; often we had to infer their beliefs from what we saw the children do and heard them say.

We intentionally gathered data from the classroom that would allow us to sort out these different theories. For example, we watched the children, keeping in mind a study done by Dahl and Freppon (1991) in several low-socioeconomic, whole language and skills-based kindergarten classrooms.
In that study, Dahl and Freppon observed kindergartners' responses to literacy engagements and identified three learning stances: Stance A, Stance B, and Stance C. Children exhibiting Stance A displayed a dependency on the teacher's instruction and a cautious or negative attitude toward literacy activities. Children exhibiting Stance B showed attentive engagement with written language but a reluctance to try new or unfamiliar tasks without support. And Stance C children enjoyed intense engagement with literate activity and had a personal agenda for learning about reading and writing.

It is not surprising that at the end of the kindergarten year the Stance $\mathrm{C}$ children were beginning readers and writers while the Stance A children were just understanding the intentionality of written language. The Stance A children were writing strings of letters and assigning meaning to their writing but were not yet using the alphabetic principles of writing independently. When the Stance A children of the whole language classrooms were compared to Stance A children in a skills-based classroom, the researchers found that the children's development reflected the assumptions of the instruction. The whole language students were aware that print carries meaning and can be used to get things done, whereas their counterparts in skills-based classrooms were focused on letters and standards of correctness or accuracy. They were more interested in the details of written language than the function.

While the difference between these two endpoints of kindergarten curricula is subtle, we believed that the whole language endpoint was much more educative than the skillsbased endpoint. Newer views of literacy helped us to understand that literacy is functional. It is our primary tool for knowing and acting on the world, yet schools have treated literacy as a skill to be learned separate from function, as a set of skills to be mastered in the context of school and then applied in the world outside. The problem with this old view of literacy, which is still prevalent in the culture at large, is that children mislearn what literacy is. The kindergartners in the skills-based classroom, in keeping with a traditional view of literacy, learned that letters and accuracy are the most important aspects of literacy. Without meaning to, perhaps, the teachers instilled in these students the idea that literacy is about manipulating abstract symbols according to a set of rules. Although this insight is important, it presents literacy as separate and disconnected from life rather than essential to living and knowing the world.

Rosenblatt's contention that our purposes for reading shape the experience (Rosenblatt, 1978) has not been translated equitably into curriculum. Students like the Stance C kindergartners are apt to discover, either in school or on their own, that reading can be aesthetic. In a study of "good" readers, Langer (1989) found that her subjects created a 
"personal text-world" that incorporated their assumptions and things imagined on the basis of the text. She noted that this world stayed with the readers even after the reading was completed and could be discussed and critiqued. In a similar study of "poor" readers, Purcell-Gates (1991) found that poor readers did not create a text world. Rather, they read literary text from an efferent stance, using their energy to gather information and reacting to the text as if it were bits of isolated information. Each idea they read was like a stepping stone along the way rather than a connected idea that further illuminated the whole.

In other words, if we are not careful, we teach students with differences different things about literacy without meaning to do so. School curriculum that is focused on teaching students to accurately encode and decode written language and to answer the teachers' questions about texts does not provide poorer students with access to the full range of literacy's potential. They may learn to produce and process written language, but they also develop personal theories of how reading and writing work that diminish their ability to use literacy to make sense of the world.

To ensure that the students in our first-grade classroom were developing functional views of literacy, we talked often with them about their beliefs and values in relation to reading and writing and using other sign systems. We also did things to demonstrate our own beliefs. For example, we demonstrated writing for many purposes and reflected on our own aesthetic experiences with shared books. We built reflective writing into the classroom routine at both the beginning and the end of the day, starting with morning journals and ending with learning logs, so that the children saw writing as a means of knowing more about themselves and one another and as a way of consolidating learning. We also integrated writing into the life of the classroom. We asked the students to write throughout the day, recording their problem-solving processes, doing research, and writing stories. We offered an invitation we called Photo Reflection (Burke, 1990). To create this invitation, we kept a camera in the classroom and snapped photos of the children engaged in different learning activities. Then we simply placed a stack of these photos on a table and invited the children to choose pictures of themselves, to tape a picture to a piece of paper, and to write about what they were doing in the photo and why they were doing it. The children's responses provided a wonderful window onto their notions of learning and the role of literacy.

\section{PETER'S STORY}

Our assumptions about literacy allowed us to design our curriculum so that multiple sign systems were introduced and available for use, so that the children's inquiry questions were central to the work of the classroom, and so that we heard the theories and thinking of the children as they worked. Our assumptions also provided us with new lenses for assessing how the children were learning. We watched to see how the children worked with various sign systems. We were always assessing their language literacy development, but we were also watching how the other sign systems supported that development or supported other kinds of thinking and growth. We watched to see what questions and interests sparked each student and how inquiries unfolded and added to students' knowledge. We also tried to understand what the students believed and understood about literacy and learning. We were interested in their personal theories of the world and their role in it.

The story that follows is Peter's story. Most of the children in the class were fairly predictable. They liked the engagements we offered and showed steady growth in all areas of the curriculum. Peter, however, was a puzzling child. Susan and I worried about Peter. We could see that he was learning, but even at the end of the school year he did not have reading and writing fully under control. We made it a point to collect work from Peter and to systematically study his artifacts, videotapes of him at work, and recorded conversations. We learned a great deal about Peter and about our teaching by doing this. His unique development is shared here in three "snapshots," each representing an interval of about a month of time.

\section{September/October}

During the first few weeks of school, Peter appeared to have some important strengths. His early attempts at writing were fairly successful. He was aware of environmental print and could copy off the board. He knew how to write all of the letters in the alphabet, even though he didn't always know the letter names. His September 13 journal entry, in which he wrote the single word "Dad," was typical of this time period. In most of his journal entries he would write just one word, often one he had in his word bank or one of the few he knew by memory. He had to be encouraged to write anything more, but with help he could work out letter/sound correspondences. If we said a word slowly for him and stopped after each consonant, he could often recognize and write the letter, as he did when writing DATBIK for "dirtbike" (Figure 1).

As time progressed, however, it became clear that Peter had some negative feelings toward language activities. He continued to limit his writing to single word efforts, and when a guest playing the part of the "Pilgrim Lady" asked the children sitting at her feet if they would like to hear a story, Peter emphatically answered, "No!" While most of the children soaked up details and information from the nonfiction texts Susan read to them about the Pilgrims and Native 

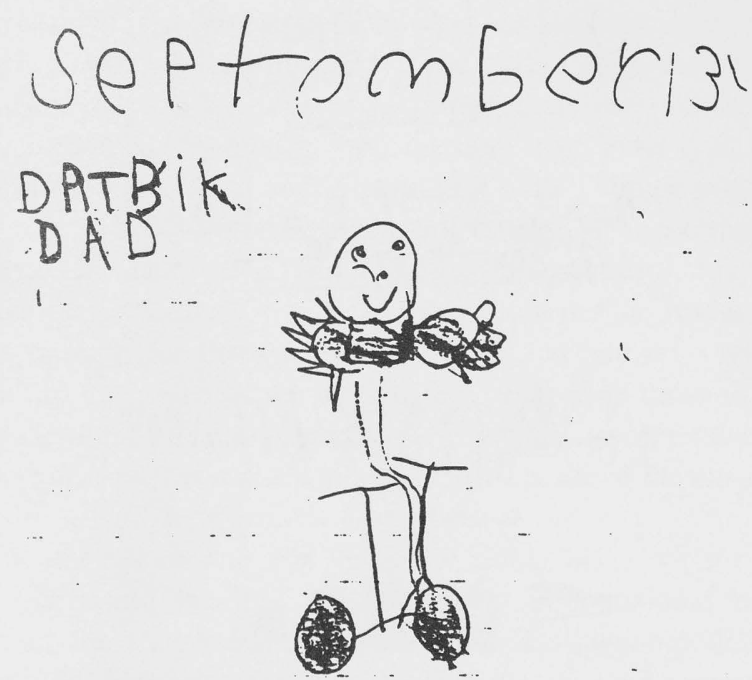

FIGURE 1

Americans, Peter seemed to let the texts wash over him. He knew, for example, that corn was mentioned in the stories, but he had no recollection after hearing the stories of who taught the Pilgrims to plant corn or why it was important.

On October 8, as Peter and I were walking down the hall, he confided, "I didn't want to come to school today because I can't read." I assured Peter that he was a beginning reader and pointed out a couple of things in the hallway that he could read-the signs on the bathroom doors, the exit signs, and the word "rainbow" on a bulletin board. But my message and the model of literacy we promoted in the classroom did not align with messages he was getting at home and elsewhere in the school. At Back-to-School Night, Peter's father looked at his journal and asked why Peter's invented spelling had not been marked wrong or corrected. Both of Peter's parents were concerned that Peter could not read the words in the predictable books that he brought home. In spite of Susan's encouragement to keep supporting Peter's reading and to watch for development in his writing, his parents began to make Peter study a set of 10 words each week. He had to practice spelling the words correctly and was either grounded or allowed to play with his friends based on what happened when his father tested him each Friday. In addition, Peter's kindergarten test scores earmarked him for Title I services, and he was being pulled out of the classroom every day for half an hour to work with a special tutor who insisted on drilling him on letters and sounds.

It was not hard to understand why Peter was unsure of himself. He was getting many mixed messages from the adults in his life, and Susan and I were not having much success in changing any of that. We knew that we could not let Peter give up on himself. In fact, we pushed him a little harder and gave him a little more support than the other children when we were reading and writing, and he did maintain a willingness to try. He liked the social aspects of the literacy rituals in our classroom. For example, he loved to share his journal with the class because he was expected to make eye contact with his peers and wait for their attention before beginning to read. He could stretch this into a long, dramatic process of looking one by one into the faces of his classmates, and someone almost always had to encourage him to get on with his sharing. While his journal entries were often only single words, this preliminary bid for attention often made his turn at sharing seem just as substantial as the sharing done by children who had written longer texts.

Our multiple sign systems learning environment included a Reflection Center. It consisted of a shelf full of scrap paper, yarn, glue, crayons, a stapler, scissors, and so forth, a table to work on, and a bulletin board for displaying finished work. During "invitation time, " or choice time, each day, Peter would mainly work at this Reflection Center. The invitation was simply to use the tools and media at the center to reflect on the current literature study or the inquiry in process. Peter seemed to understand the purpose of the center, as he explained that "you go there to think about what you are doing."

At the Reflection Center, Peter created three-dimensional artifacts that mirrored their concrete counterparts. For example, he made a "pocket" by stapling two papers together. His creations suggested that Peter was focused on an important literacy concept that Howard (1992) described as "showing forth" and Dyson (1991) described as "establishing equivalences." He was focused on the ways signs are connected to the real world. Using the paper and staples, he created what he designated as a sign for "pocketness." Dyson said this is a first step in discovering how to transform the experienced world into an imagined one. It amounts to realizing that a visible sign can represent invisible prior experiences or, in this case, the invisible concept of pocketness.

At the Reflection Center, Peter made things like a quiver full of paper arrows, three-dimensional numbers, and a replica of a wigwam. While his written language productions were minimal, the works he created at the Reflection Center were often fairly complex and required a great deal of concentration. What he was not able to do with language, he was able to do with drawing and three-dimensional paper sculpting. He could concentrate and reflect in depth. He could make things mean what he wanted them to mean, and he could connect what he was thinking to events in the curriculum. As I reviewed video footage recorded in the classroom during September and October, I noticed that Peter 
seldom talked during writing or reading activities. Yet, he carried on active conversations with those around him when he was at the Reflection Center or creating a drama or doing anything of a physical nature. He especially came alive during recess and joined any kind of ball game he could find.

\section{November}

By November, Peter was able to move into his zone of proximal development (Vygotsky, 1978) in experiences that involved sign systems other than language, but he was not doing so with his reading choices. Each week, Susan offered the children a choice of four or five literature study books. She provided time for the children to browse through the books and expected them to choose the one they wanted to read and discuss. The selections ranged from extremely predictable books to ones with fairly complex text structures. Most of the children gave their choice considerable deliberation, reading pages of each book to see if the text was manageable, flipping through the books to look at pictures, and comparing the length of books. We noticed that Peter, however, chose the first book he flipped through. He showed no curiosity about the books and devoted no energy to finding a book that was suited to his own literacy development.

Peter's writing development was also behind that of his peers during this time period. He persisted in doing as little writing as possible. Susan finally insisted that he write sentences instead of single words in his journal, so he began every entry with "I like." Initially, he would look up the word "like" in his deck of word cards and spell it from the card, but then he began experimenting with the spellingLKIE, LIKEE, KLE, and KLIE (Figure 2). At one point, Peter and I spent 30 minutes talking about the word "like," reviewing the relationship of the sounds and the spelling, writing it on the board repeatedly, and spelling it out loud. I was sure this concentrated practice would enable him to write the word successfully in the future, but the very next day he seemed absolutely clueless about the word. His memory did not hold the orthographic pattern of the letters. Spelling a word correctly one day did not lead to spelling it correctly the next. A note from his mother, returned with his Colonial America portfolio, echoed a similar frustration. She wrote: "I wish that when I worked with Peter at home that I could make him comprehend the basics of reading and writing and that I had more patience. (We could probably get more accomplished.)"

In a conversation with Peter, I asked him how he thought a person might become a better reader and writer. Peter explained that learning in school depended on "doing what the teacher says to do." This stance echoed the first stance described by Dahl and Freppon (1991) in their study of kindergartner's literacy learning-a dependency on the teacher's instruction and a cautious or negative attitude
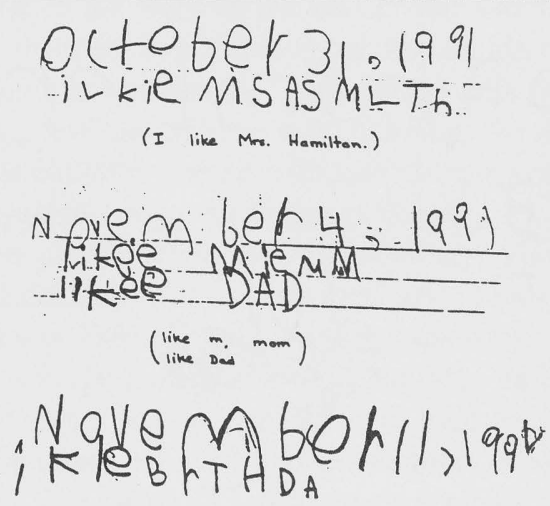

(I like birthdays.)

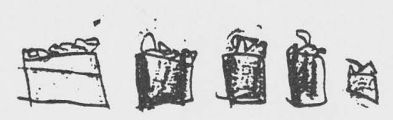

FIGURE 2

toward literacy activities. While Susan and I were not aware of how this way of thinking played out for Peter at the time, we observed later, as we watched videotapes from this time period, that Peter was learning to act literate even if he wasn't learning to read and write. He was living his theory that he needed to do what the teacher said to do. He was trying very hard. He sat attentively for stories. He labored long and hard over single word entries in his learning log, timing his finish to coincide with those students who wrote several sentences. In reading groups, the children often read predictable books out loud in unison. Peter went through all the motions in these readings, trailing his finger across the page and mouthing the words with the group, but he never made a prediction if the group got stuck. Nor did he ask questions or answer any. He learned how to watch the others when he was reading and to turn the pages at the same time they did. In fact, in the videos, we could see that he consistently did what the other children did, just a split second after them. When raising his hand to answer a question, when following a direction, or when reading in unison, he was always a beat behind, cueing off the others.

During choice time, Peter avoided invitations that involved reading and writing, but he began to try more complex tasks, such as sorting the artifacts in the Colonial America museum in Venn diagram fashion, using mathematics manipulatives to create and solve problems, and drawing portraits of himself. In these settings, he was a constructive learner. He talked his way through the tasks and recognized and solved problems. He often asked those around him for help with questions like "What is this?" and "What numbers do I write?" and "How do you draw the eyes?" 
Peter's focus on the procedural aspects of becoming literate and his passive approach to written language were also apparent in his learning log. At the end of each day, when the class spent 15 minutes recording their thoughts about what they had learned in their learning logs, Peter typically wrote a single word and illustrated it with a simple picture. Figure 3 shows Peter's learning log entries for two different days. One entry says "Mit," and he has drawn mittens; the other says "Itentes," and he has drawn an Indian. It was not uncommon for Peter to record things that had no obvious link to the concepts we were trying to develop through the curriculum. He didn't seem to grasp the concept that the learning log was a place to gather the threads of the curriculum; instead, he treated it as an isolated task.

Peter adhered to this stance of doing his work for the teacher until the day Susan read an informational book about the Plains Indians. Peter was finally compelled to record information for himself. That day, instead of writing his usual one-word entry in his learning log, he wrote a complete sentence: "I like Indians because they shoot buffaloes" (Figure 4). This particular bit of information kept him occupied for the next 2 weeks. As an inquiry question, he asked, "How did the Indians shoot buffalo?" He took this question and a book about Indians home to get help from his family. They helped him write about the weapons and the skinning of the buffaloes. He joined a poetry group whose members were memorizing a poem about buffaloes. He made arrows and knives at the Reflection Center and continued to write sentences about Indians and buffaloes for days in his learning $\log$.

\section{May/June}

Throughout the school year, drama was one of the sign systems Peter used with regularity. He especially liked the performance aspects of drama. Although he was visibly

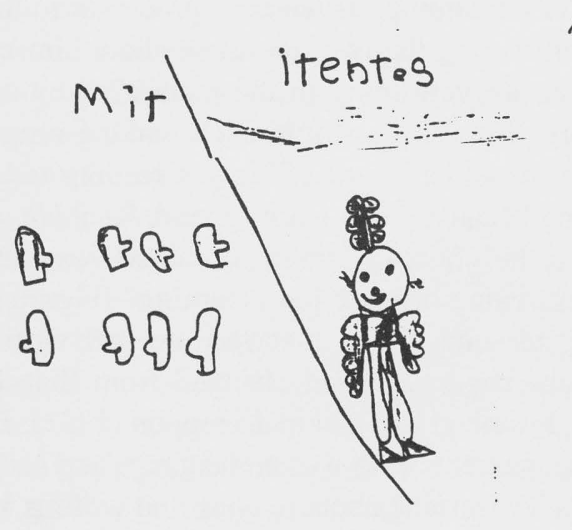

FIGURE 3

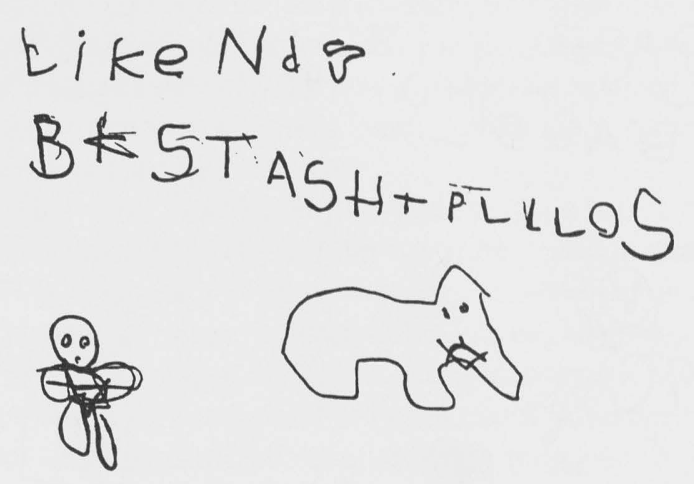

FIGURE 4

nervous when he was in front of the group early in the year, he continued to accept parts. He almost never initiated ideas in the planning and was usually told by other, more assertive youngsters what his part would be. But as the year went on, the props he made became more elaborate, and he began to act like his character in the plays.

In the last month of the school year, Peter accepted the lead in a play for the first time. He volunteered to be the Gingerbread Man. Susan had worked with the children as a class to write the script on large chart paper, and to save time, she had not written out all of the Gingerbread Man's repeated lines. Practicing for the play, Peter and a few other children were reading the script together, and the children were feeding him all of his lines because he could not remember the sequence of characters that he was to add cumulatively to his list ("I've run away from the Little Old Woman and the Little Old Man"... and the cow and the horse and the mowers and so on).

When Susan suggested that the children start to act out the parts, they set the stage so that Peter would run in a circle, and each time he came around he would meet a new character. Once the Little Old Woman and the Little Old Man had chased Peter, they stood at the edge of the circle where Peter could see them and remember to include them in his monologue. It was by doing this physical circling past characters that Peter finally grasped the structure of this cumulative tale. He had been reading cumulative tales all year with little understanding, yet he could act this one out because he figured out the underlying structure.

Kress (1998) described drama as a system that involves "acting with one's whole (social and physical) body in spatial relations to other social and physical bodies" (p. 9). This kind of learning was more powerful than print literacy in Peter's life. The power of the physical realm showed up again in a picture Peter drew of a baseball game. Shown in Figure 5, the picture reflected a new sense of structure and 


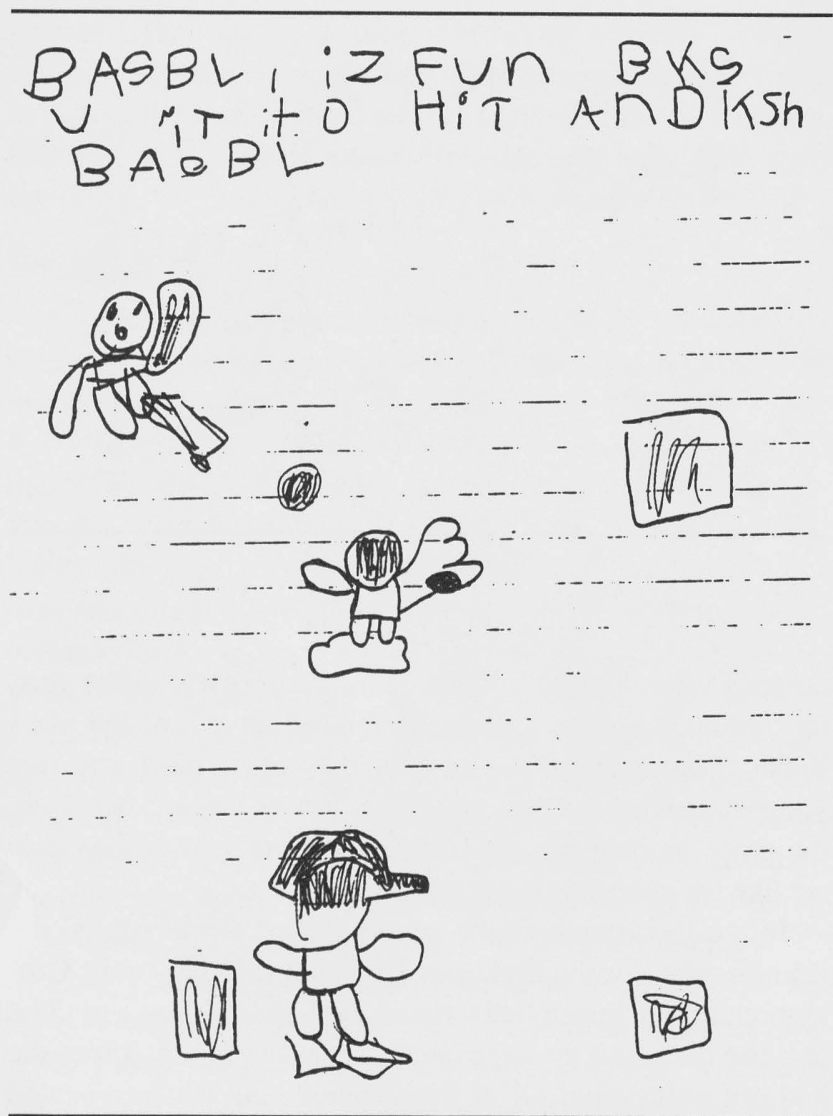

FIGURE 5

the relatedness of events. When Peter shared this picture, it helped us to understand that Peter's favored learning realm was physical and social. As he made discoveries in this physical realm, new things made sense to him in the realm of reading and writing.

Peter began to show persistence as a writer. The page of "I likes" shown in Figure 6 illustrates the kind of writing Peter did of his own free will. He was using what he finally controlled ("I like") to set up opportunities to work at the edge of his knowing. This is what he had been doing for months at the Reflection Center, and finally he was doing it in writing as well.

Peter's writing began to give more insight into his conceptual frameworks. After a field trip to a local park with a small reservoir, Peter wrote, "Today I went to Eagle Creek and I saw the ocean" (Figure 7). This sentence told us that the experience of making a papier-mâché globe and painting on the oceans and continents had some impact on Peter and that he was making connections. It also told us that unlike many of his peers who could name the oceans and understand the abstraction of a globe, Peter could not yet extend his learning beyond his concrete experiences.

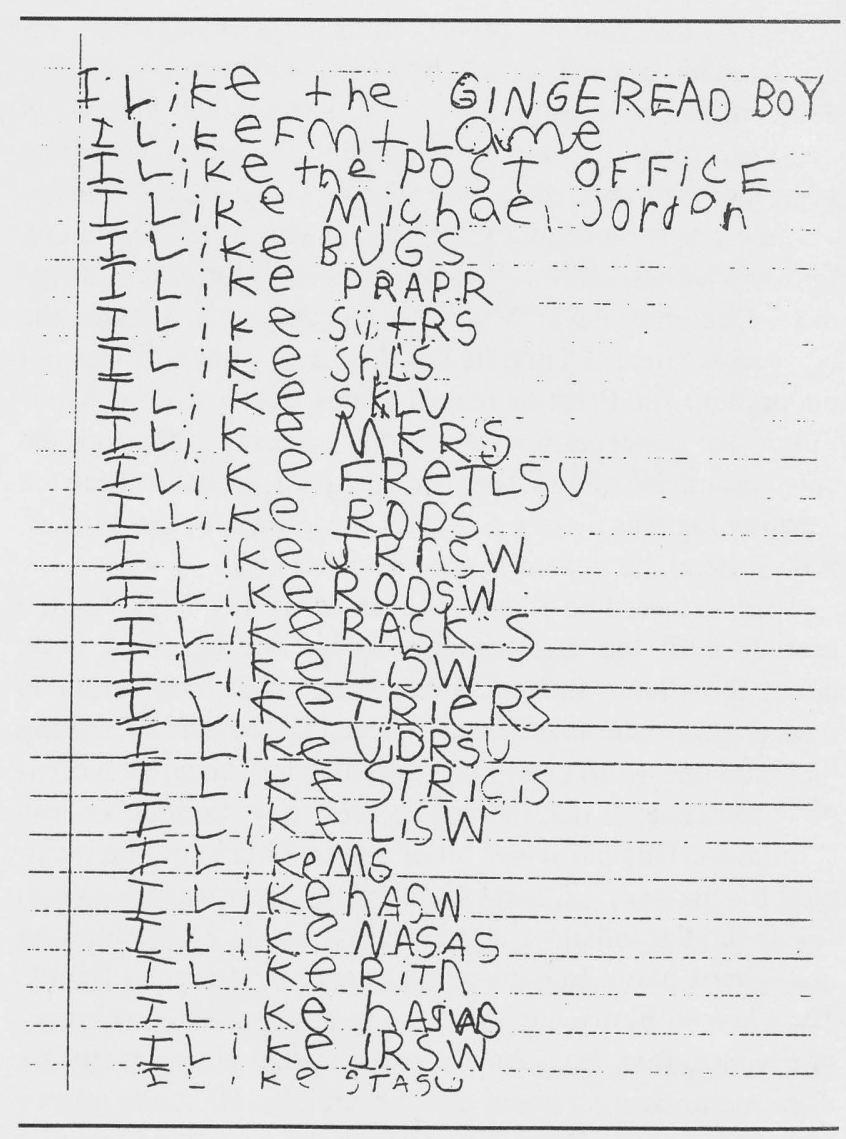

FIGURE 6

Clearly, Peter was not reading and writing up to the benchmark standards of the school, and his peers still found much of his written communication unintelligible. But Peter's sense of what he was doing, his personal theory about print literacy, had changed dramatically. During the last few weeks of school, Peter frequently visited the invitation called Photo Reflections. He finally understood the importance of explaining his learning processes to himself. He valued answering the two questions about himself as a learner: What are you doing in the picture? Why are you doing it? First, he wrote about himself making props for a play. Next, he picked a picture of himself reading and wrote, "I am reading because I can learn to read Pumpkin, Pumpkin." Finally, he chose a picture of himself writing and wrote: "I am writing because I am learning" (Figure 8).

Finally Peter understood that reading and writing are ways to learn. His stance had changed from Stance A to Stance C as described by Dahl and Freppon (1991). He was initiating engagements with written language and had a personal agenda for learning about reading and writing. He was no longer dependent on the teacher's directives or reluctant to read and write. 


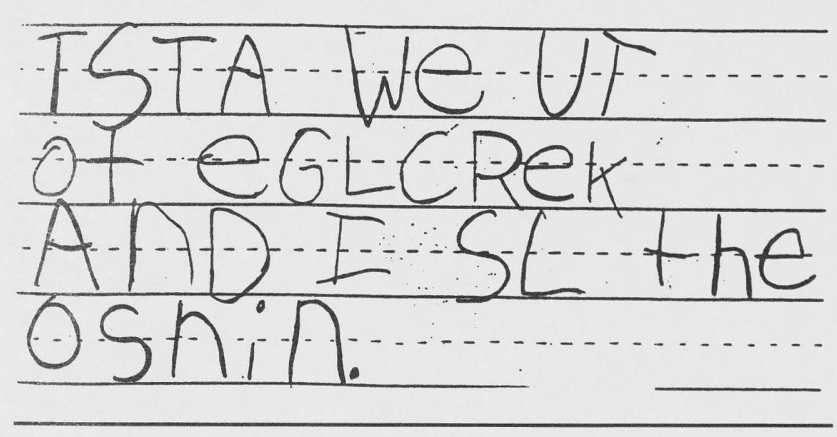

FIGURE 7

\section{Om riten \\ Because I \\ am learning}

to use print literacy to get answers to his own questions and to create texts of significance to himself. Then he had a more complete sense of what was possible. He realized that there was more to school and learning than the procedural layer of doing the task required.

In some ways, Susan and I learned the same lesson during this experience. By making a strong commitment to our own interests and questions, we also developed a deeper sense of what was possible. We began to understand that Peter might well be making important conceptual gains even though he was passive and threatened by written language. To find out if this was the case, we had to interpret what we saw Peter do. We had to gather information from many aspects of his life in the classroom. We watched him live and learn alongside his peers. We pondered his willingness to perform and his penchant for a 3 $\mathrm{D}$ world. And we were patient, because it took time for the story to unfold. It was not always clear whether our interpretations were valid or how the larger pattern of Peter's development would evolve.

We started using the notion of aesthetic to talk about our experience of coming to know Peter as a learner because it captured the essence of our experience. We were comparing our interpretations and continually gathering information to make Peter more predictable to us. We found ourselves generating questions like the following to guide our observations: What sign systems does he favor? What does he understand about using those sign systems? What interests and questions are compelling to him? What are his theories about literacy, school, and the world?

By taking an aesthetic stance toward the assessment of Peter's learning, we realized that we could do a better job of teaching Peter. Our strategy of providing choice time each day during which students could work at things their own way was a good one for Peter. But we also did a great deal of instruction that did not connect well to Peter. We were teaching about globes and corn and history before Peter had the schema to use this information. We needed to keep in mind that he was at a different phase of development than the other students and needed more concrete support. It was not enough to mention corn. We needed to bring in the stalks of corn and husk the ears. We needed to do lessons with the children that worked at many levels. Peter needed to put his hands on the corn, to smell it, to taste it, and to dissect it, while other children were ready to graph the number of sheaves in a husk and to study corn's Native American origins.

As we organized our observations and data from the classroom to write Peter's story, we found support for the assumptions about literacy that we were using to frame our curriculum. We saw turning points in Peter's literacy development that originated in sign systems other than language. For example, we saw that he worked out the concept of 
equivalency by constructing 3-D models of things in the real world. If a paper sculpture could stand for a real-world object, so then could a word. He also learned about story structure through drama. The physical act of running in circles helped Peter understand the nature of a cumulative story. He transferred this realization to reading and began to read predictable books that had a cumulative structure with more assurance.

Peter demonstrated that literacy supports inquiry when he started to pursue his question about how Native Americans killed buffaloes. He discovered that many of the things people have learned are written down. If he could locate and reconstruct the information from a text, or if he could find someone to read the information to him, he could know important things in detail, like the length of the knives used to kill buffaloes or the Native American's tricks for getting close to the buffalo. It was another turning point when Peter learned that he could use literacy to support his personal inquiry.

Finally, we saw our assumption that literacy is shaped by theories illustrated in Peter's story as well. In the beginning of the year, Peter was a victim of conflicting theories. On the one hand, he was learning that spelling was the most important aspect of literate work; on the other hand, he was encouraged to invent spelling and to write for meaning. It is little wonder that he took up the stance of least resistance-do what the teacher tells you to do, leave it to the teachers to know what is best. Fortunately, he moved beyond this dependency, and by the end of the year, he believed that he could establish his own learning challenges. He even explained in an interview at the end of the year that we should help the next group of first graders understand that they could learn to read and write by reading and writing and being artists.

Looking back, we can see that we missed some potential learning opportunities with Peter. He was learning all kinds of things from playing ball, but we were not tuned in. In fact, our learning environment made little provision for knowing the children in terms of movement and physical activity. As we think about Peter and some of the other boys in the room, we realize that kinesthetic knowing might well be their most cogent mode of knowing. So we have new questions about how to set up the learning environment and where we should go to watch our children learn.

When we took an aesthetic stance toward literacy, curriculum, and assessment, we made lived experience central to our thinking and thereby changed the texture and quality of our work. We liked the change. We were in control, interacting to clarify our own thinking and following our own interests and questions. We put ourselves in a position to see learning in multiple ways and to learn about learning by watching the children. We were alive and thinking in the classroom, not just doing the tasks expected of us. Like Peter, we came to understand the possibilities of school differently. We discovered that we could know our children so well that we could teach to their strengths and talk with them about their theories of learning and literacy. We think this is exactly the kind of teaching and assessment that serves all children well.

\section{REFERENCES}

Berghoff, B. (1994). Multiple dimensions of literacy: A semiotic case study of a first-grade nonreader. In C. Kinzer \& D. Leu (Eds.), Multidimensional aspects of literacy research, theory, and practice (pp. 200-208). Chicago: The National Reading Conference.

Berghoff, B. (1998). Multiple sign systems and reading. The Reading Teacher, 51, 520-523.

Burke, C. (1990, Fall). Seminar in curriculum and instruction, Indiana University, Bloomington.

Csikszentmihalyi, M. (1996, Summer). How to measure learning. The Insti tute View. Los Angeles, CA: The Paul Getty Center for Education in the Arts.

Dahl, K., \& Freppon, P. (1991). Literacy learning in whole-language classrooms: An analysis of low socioeconomic urban children learning to read and write in kindergarten. In S. McCormick \& J. Zutell (Eds.), Learner factors/teacher factors: Issues in literacy research and instruction (pp. 149-159). Chicago: The National Reading Conference.

Dyson, A. H. (1991). Viewpoints: The word and the world-reconceptualizing written language development or do rainbows mean a lot to little girls? Research in the Teaching of English, 25, 97-123.

Harste, J., Woodward, V., \& Burke, C. (1984). Language stories and literacy lessons. Portsmouth, NH: Heinemann.

Howard, V. A. (1992). Learning by all means: Lessons from the arts. New York: Peter Lang.

Hubbard, R. (1989). Authors of pictures, draughtsmen of words. Portsmouth, NH: Heinemann.

John-Steiner, V. (1985). Notebooks of the mind: Explorations of thinking. Albuquerque: University of New Mexico Press.

Kress, G. (1998). "You just got to learn how to see": Curriculum subjects, young people, and schooled engagement with the world. Unpublished manuscript.

Langer, J. (1989). The process of understanding literature (Report Series 2.1). Albany, NY: State University of New York, Center for the Learning and Teaching of Literature.

Mills, H., \& Clyde, J. (Eds). (1990). Portraits of whole language classrooms. Portsmouth, NH: Heinemann.

Newkirk, T. (1989). More than stories: The range of children's writing. Portsmouth, NH: Heinemann.

Purcell-Gates, V. (1991). On the outside looking in: A study of remedial readers' meaning-making while reading literature. Journal of Reading Behavior, 23, 235-253.

Rosenblatt, L. (1978). The reader, the text, the poem. Carbondale: Southern Illinois University Press.

Shannon, P. (1990). The struggle to continue: Progressive reading instruc tion in the United States. Portsmouth, NH: Heinemann.

Short, K., Schroeder, J., Laird, J., Ferguson, M., \& Crawford, K. (1996). Learning together through inquiry: From Columbus to integrated curriculum. York, ME: Stenhouse.

Vygotsky, L. (1978). Mind and society: The development of higher psychological processes. In M. Cole, V. John-Steiner, S. Scribner, \& E. Souberman (Eds.), Cambridge, MA: Harvard University Press. 